11. Slonimsky N., Kuhn L. Baker's Biographical Dictionary of Musicians. Vol. 4. New York : Schirmer Reference, 2001. 4500 p.

\title{
References
}

1. Kovnatskaya, L. (1989). English music of the twentieth century. The origins and the stages of development. Moscow: Sovetskiy kompozitor [in Russian].

2. Allis, M. (2003). Parry's Creative Process. Surrey: Ashgate [in English].

3. Burton, A. (n.d.). Hubert Parry Biography (BBC). [online]. Available at: https://www.bbc.co.uk/music/artists/e58a0544-2b32-47b2-955c-fa51887ec6c7 [Accessed 23 May 2019] [in English].

4. Dibble, J. (1992). Hubert H. Parry. His Life and Music. New York; London: Oxford University Press [in English].

5. Eatock, C. (2010). The Crystal Palace Concerts: Canon Formation and the English Musical Renaissance. 19 $9^{\text {th }}$ Century Music, 34, No 1, pp. 87-105 [in English].

6. Fuller-Maitland, J. (1919). Hubert Parry. The musical quarterly, 5, No 3, pp. 299-307 [in English].

7. Howells, H. (1969). Hubert Parry. Music and Letters, 50, No 2, pp. 223-229 [in English].

8. Legge, R. (1918). Charles Hubert Hastings Parry. The Musical Times, 1 November, pp. 489-491 [in English].

9. Manning, D. (2007). Vaughan Williams on Music. London: Oxford University Press [in English].

10. Morris, R. (1920). Hubert Parry. Music and Letters, 1, No 2, pp. 94-103 [in English].

11. Slonimsky, N., Kuhn, L. (2001). Baker's Biographical Dictionary of Musicians. Vol. 4. New York: Schirmer Reference [in English].

УДК 780.616.432.082.4+780.614.331.082.4]:78.071.1(430)

DOI: https://doi.org/10.33643/kmus.2019.58.09

Денис Кашуба, аспірант кафедри інтерпретологї та аналізу музики Харківського національного університету мистеитв імені І. П. Котляревського https://orcid.org/0000-0002-9438-2200 pianodk93@gmail.com

Denys Kashuba, Postgraduate student of the Department of Interpretation and Analysis of Music, Kharkiv National Kotlyarevsky University of Arts https://orcid.org/0000-0002-9438-2200 pianodk93@gmail.com

\section{ПЕРШИЙ ФОРТЕПІАННИЙ КОНЦЕРТ Й. БРАМСА ТА СКРИПКОВИЙ КОНЦЕРТ Р. ШУМАНА: ПРИСВЯТА ЧИ РЕМІНІСЦЕНЦІЯ?}

Актуальність теми зумовлена потребою осягнути музичні твори Й. Брамса в аспекті його «шуманіани». Мета дослідження - здійснити аналіз фортепіанного концерту Й. Брамса в контексті шуманівських ідей. У 
статті використані методи музичної компаративістики 3 позиції осмислення авторської присвяти в нотному тексті. Результатом дослідження стало встановлення подібностей та розбіжностей між обраними творами. Робиться висновок, що аналогії, які виникають між двома концертами, мають характер не присвяти, а ремінісценції.

Ключові слова: присвята, ремінісценція, концерт, Й. Брамс, Р. Шуман.

Kashuba Denys. The First Piano Concerto by J. Brahms and the Violin Concerto by R. Schumann: a dedication or reminiscentia? The relevance of the topic is related to the desire to comprehend the distictiveness of J. Brahms' compositions in the aspect of his «schumanniana». The purpose of the study is to consider the First Piano Concerto by J. Brahms in the aura of Schumann's musical ideas. The paper uses the research methods suggested by N. Fomina when studying the phenomenon of dedication in the musical text, as well as the means of musical comparativism. Findings of the study. The first opus compositions by J. Brahms reveal all sorts of borrowings. This also regards his First Piano Concerto, which evokes analogies to the Violin Concerto of R. Schumann. J. Torgan even wonders whether this composition by J. Brahms was not intended as a dedication to R. Schumann. He does so basing on the tonality of both pieces (d-moll) and similarity of their «title» themes that resurrect the image of the Baroque era. However, R. Schumann is known to have stylized his concerto, which is seen in the first part of the cycle that corresponds to the alternation algorithm of tutti and solo in a baroque concerto form, whereby the relief thematism of tutti sections alternates with the figurative thematism of solo parts. Baroque techniques are also used in the second part of R. Schumann's concerto, and in the final the thematism of various origins is combined with the carnival principle. J. Brahms thinks in terms of sonatasymphonic logic, he does not have any stylizations, although he uses the phenomena of Baroque music as fixed units of a generally significant musical vocabulary. Thus, the identified similarity between the works mentioned does not serve as a sufficient basis for interpreting the concerto of J. Brahms as dedication to R. Schumann, however, it allows to see in it a response to the above mentioned opus, taking into account the multidirectional connections between both composers - the reminiscentia of Brahms' «schumanniana».

Keywords: dedication, reminiscentia, concerto, J. Brahms, R. Schumann.

Кашуба Денис. Первый фортепианный концерт И. Брамса и Скрипичный концерт Р. Шумана: посвящение или реминисценция? Актуальность темь связана со стремлением постичь своеообразие 
музыкальных произведений И. Брамса в аспекте его «шуманианы». Цель исследования заключается в рассмотрении Первого фортепианного концерта И. Брамса в ауре шумановских музыкальных идей. В статье использованы методы музыкальной компаративистики с позиции осмысления авторского посвящения в нотном тексте. Результаты исследования. Первые же опусные произведения И. Брамса обнаруживают всевозможные заимствования. Это касается и его Первого фортепианного концерта, вызывающего аналогии со Скрипичным концертом Р. Шумана. Я. Торган даже задает вопрос, не было ли данное произведение И. Брамса задумано как посвящение Р. Шуману. Основанием для этого служат тональность обоих сочинений $(d$-moll), а также сходство их «титульных» тем, воскрешающих образ эпохи барокко. Однако Р. Шуман, в отличие от И. Брамса, занимается стилизацией, которая распространяется на композицию первой части цикла. Здесь Р. Шуман использует алгоритм чередования tutti и solo в барочной концертной форме, причем рельефный тематизм туттийных разделов чередуется с фигурационным тематизмом сольных. Барочные приемы наблюдаются также во второй части концерта Р. Шумана, а в финале тематизм различного происхождения объединяется карнавальным принципом. И. Брамс мыслит сонатно-симфонической логикой, не занимается стилизацией, хотя и использует явления барочной музыки в качестве устойчивых единиц общезначимого музыкального словаря. Тем самым, выявленное сходство названных произведений не служит достаточным основанием для трактовки концерта И. Брамса как посвящения Р. Шуману, однако позволяет усматривать в нем отклик на названный опус, а с учетом разнонаправленных связей между обоими композиторами - реминисценцию брамсовской «шуманианы».

Ключевые слова: посвящение, реминисценция, концерт, И. Брамс, Р. Шуман.

Постановка проблеми. Питання про співвідношення творчих феноменів Р. Шумана та Й. Брамса є багатоаспектним. Його розкриття 3 культурно-історичних позицій містить можливість осмислення безперервної еволюції німецького романтизму XIX століття; 3 індивідуально-особистісних - встановити збіг літературних смаків композиторів; 3 художньо-естетичних - виявити подібність цільового завдання: злиття у нерозривній єдності явищ та принципів організації, притаманних різним музично-історичним стилям. У суто творчому сенсі Р. Шумана та Й.Брамса зближує схильність до всіляких шифрів та символів, способи організації музичного часу та простору, витончена 
мотивна техніка та ін. Показово також, що улюблений пізнім Й. Брамсом жанр фортепіанного інтермецо - «шуманівського» походження. У світлі окресленого кола зв'язків між двома музичними геніями питання про подібності Першого фортепіанного концерту Й. Брамса та Скрипкового концерту Р. Шумана набуває проблемного характеру, хоча i виступає окремим випадком прояву глибинної спорідненості німецьких композиторів, які належать різним етапам історико-стильового становлення музичного мистецтва XIX століття.

Актуальність теми. Безпосередні творчі стосунки Р. Шумана та Й. Брамса продовжувалися всього два з половиною роки: з жовтня 1853 по липень 1856, тобто до самої смерті першого з них. Вони досить докладно описані у двох розділах монографії про Й. Брамса К. Царьової [5]. Сукупність викладених фактів дозволяє вченому дійти важливого висновку про генетично-запрограмоване продовження Й. Брамсом шуманівської лінії в національному романтизмі, успадкування їм «відповідальності за долю німецької музики» [5, с. 51], про яку піклувався протягом всього свого життя Р. Шуман. Втім, хоча в процесі подальшого дослідження творів Й. Брамса музикознавець постійно звертається до окремих паралелей 3 творчістю Р. Шумана, питання про власне музично-текстові контакти між ними не стають в даній книзі предметом спеціального розгляду. Отже, виникає необхідність встановлення конкретних форм прояву «шуманівського» в музичних текстах Й. Брамса. Це є одним з оптимальних шляхів розкриття сутності творчого союзу двох унікальних особистостей, що належать до світового «симпозіуму» геніїв мистецтва.

Новизна обраної теми. Відповідь на запитання про ймовірність присвячення Р. Шуману Першого фортепіанного концерту Й. Брамса через його схожість зі Скрипковим концертом гіпотетичного адресата, одержана в результаті дослідження, має принципове значення. I не тільки для встановлення правомірності подібних припущень, але й для більш широких висновків про сутність численних проявів спорідненості авторів розглянутих творів, що відкриває шляхи до удосконалення теоретичної бази і аналітичних інструментів музичної компаративістики.

Мета дослідження полягає в розгляді Першого фортепіанного концерту Й. Брамса в контексті шуманівських музичних ідей.

Завдання досліджсення: Здійснити порівняльний аналіз художніх концепцій Першого фортепіанного концерту Й. Брамса та Скрипкового концерту Р. Шумана та на цьому підгрунті встановити сутність спорідненості творчих ідей Р.Шумана та Й. Брамса; визначити 
спорідненість творчих ідей обох композиторів шляхом використання відповідного наукового поняття.

Методи дослідження. Проблемний аспект вивчення теми «Р. Шуман - Й. Брамс», обраний для розробки в даній статті, обумовив звернення до поняття присвяти в нотному тексті. Досліджуючи його, Н. Фоміна розуміє під «присвятою» словесні звернення до певних осіб, що передують викладенню нотного тексту та в деяких випадках набувають вигляду власне музичних явищ [4]. Виходячи 3 цього, можна дійти висновку про існування присвяти в двох формах: словесній та музичній, відповідно, як коментаря до композиторського твору та частини його художнього змісту, причому перша з них є вирішальною, обов'язковою. Показово, що знаходячи тематичні запозичення 3 чужої музики у фортепіанних опусах Р. Шумана поза словесних вказівок, О. Меркулов визначає їх не як присвяту, а за допомогою поняття «звукові символи» [2]. Втім, враховуючи потаємність особистості Й. Брамса, який неохоче розкривав свій композиторський світ через уживання словесних повідомлень, можна припустити, що у випадку з паралелями між його Першим фортепіанним концертом і Скрипковим концертом Р. Шумана він уникнув відкритого посилання на твір свого старшого сучасника, але натякнув на його наявність суто музичними засобами. Для розв'язання цього питання в статті використовується компаративний підхід до обраних опусів, який передбачає, за Н. Гуляницькою, зокрема, «порівняння творів різних авторів - одного чи не одного історичних періодів [1, с. 72].

Результати дослідження. 3 перших опусних творів у молодого Й. Брамса виявляється схильність до усіляких запозичень. Initio першої частини його сонати $C$-dur op. 1 являє собою алюзію на початкові такти Сонати B-dur op. 106 Л. ван Бетховена, а друга тема Скерцо es-moll op. 4 є цитатою 3 опери «Ханс Хайлінг» Г. Маршнера. Більш того, Й. Брамс викладає свою думку у фактурі «золотого ходу валторн», подібно до того, як в оригіналі вона доручається соло цього інструмента. Отже, відразу розкривається тяжіння Й. Брамса до використання чужого матеріалу. Те саме стосується його Першого фортепіанного концерту, тематизм якого відсилає до Скрипкового концерту Р. Шумана.

Символічно, що перший візит юного Й. Брамса до подружжя Шуманів співпав 3 днем завершення Робертом саме даного опусу - 1 жовтня 1853 року. 3 цього моменту життя та творчість Й. Брамса виявилися тісно пов'язаними з їх родиною аж до смерті Клари у 1896 році- за рік до смерті Й. Брамса. Цей відомий факт також провокує дослідників на пошук шуманівських музичних ідей у Першому 
фортепіанному концерті Й. Брамса. К. Гейрінгер наводить цікаві, нерідко курйозні інтерпретації концерту під знаком програмності. Наприклад, в образах першої частини бачили втілення того враження, яке на Й. Брамса справила невдала спроба самогубства Р. Шумана. Шуманівські алюзії знаходили й у другій частині. Посилаючись на іi назву, яка спочатку містилась в рукопису («Благословенний той, хто 3'явився від імені Господа»), прихильники позамузичних тлумачень концерту бачили відображення поклоніння композитора своєму старшому другові, до якого він звертався «Господь». Не погоджуючись 3 такого роду тлумаченням, музикознавець, тим не менш, допускає зв'язок змісту другої частини Концерту зі ставленням Й. Брамса до Клари [7, с. 250-252]. Аналогії між Першим фортепіанним концертом Й. Брамса та Скрипковим концертом Р. Шумана виникають також й у К. Царьової [5, с. 289]. Питання про задум даного опусу Й. Брамса як присвяти Р. Шуману піднімає і Я. Торган. Він вважає малоймовірним припущення про вплив на характер музики концерту життєвої катастрофи Р. Шумана. Разом 3 тим, відзначаючи близькість твору Й. Брамса Скрипковому концерту його старшого сучасника, дослідник задається питанням, чи не був Перший концерт «задуманий як присвята Р. Шуману» [3, с. 12].

Підставою для такого роду аналогій та здогадок служить єдина тональність обох творів - $d$-moll, а також спорідненість їх «титульних» тем. Обидві вони воскрешають образи епохи бароко. Збіг між ними стосується таких деталей, як пунктирний ритм в неквапливому русі (Maestoso у Й. Брамса, In räftigem, nicht zu schnellem Tempo у Р. Шумана), трелі, потужні злети тіратоподібних пасажів, широкі імперативні ходи, поліфонізація фактури. Але орієнтуючись на музичні традиції бароко, кожен 3 композиторів знаходить для цього свій підхід. Р. Шуман займається стилізацією, що проявляється, зокрема, в мірній ході басів 3 риторичною фігурою кроку і зверненні до типової для бахівської епохи діатонічної секвенції. Стилізаторські наміри композитора розповсюджуються і на структурно-композиційну організацію першої частини циклу, відсилаючи до сценарію і алгоритму чергування tutti та solo в барочних скрипкових концертах А. Вівальді. Усі tutti засновані на вихідній темі та утворюють розгорнуті розділи. Винятком є перше 3 них, де панування презентованого музичного матеріалу на короткий час відступає перед ліричною темою $B$-dur, dolce, $p$ в дусі пісенноромантичних висловлювань, після чого повертається невпинна імперативність барочного тематизму. Відповідно до принципів побудови перших частин концертів XVIII століття, tutti повторюється чотири рази зі 
змінами лише у ладотональній сфері: $d$-moll $-F$-dur $-d$-moll $-D$-dur. На противагу чіткій тематичності оркестрових висловів, сольні виявляють схильність до фігураційності, що у бароковому концерті пов'язувалося 3 метою демонстрації солістом майстерності у володінні віртуозною моторикою. Отже, в першій частині Скрипкового концерту Р. Шумана стає очевидною побудова за бароково-концертною схемою: $R-I-R-I-R-I-R$, де $R$ - ритурнель, $I$ - інтермедія. В таких умовах діалог оркестру і соліста набуває інших форм у порівнянні з симфонізованими концертами класиків i романтиків, тим більше, що Р. Шуман послідовно уникає спілкування комунікантів, обмежуючись в інтермедіях простим акордово-гармонічним супроводом оркестру. Лише в ліричних «відступах», які доручаються солістові, оркестр підключається до сумісної гри через мелодійне забарвлення партитури, що $є$ типовим для взаємодії соліста й оркестру романтичної доби. Таким чином, у проаналізованому творі Р. Шумана встановлюються два типи сольно-оркестрового діалогу: умовно концертнобароковий, котрий забезпечує «чистоту» жанру, та симфонічний, притаманний класицизму й романтизму.

Наявність в Скрипковому концерті Р. Шумана історично різних стилістик, виділених в окремі розділи, дозволяе встановити в його першій частині дію сонатної композиційної логіки. Про доречність такого спостереження свідчить образно-тематична «персоніфікованість» партій оркестру та соліста, що співвідносяться як «позаособистісне особистісне», «фатально-приречене - рефлексивне», «епічне - ліричне», «зовнішнє - внутрішнє». Таке протистояння обумовлює проникнення в шуманівський концерт діалогу-антитези, притаманного симфонічному мисленню. Цілком природним $є$ звернення композитора до принципів сонатної побудови першої частини Концерту. Пристосування концертної логіки, заснованої на принципі антифону, до драматургії образностилістичних протиставлень симфонічного типу обумовило повернення Р. Шумана до подвійної експозиції. Цей прийом і в класичному концерті зберігав генетичний зв'язок із бароковою опозицією tutti - solo, але найчастіше містив таку сонатну ознаку, як образний та тональний контраст. У Скрипковому концерті Р. Шумана перша експозиція дорівнює вихідному ритурнелю - tutti; друга - першій інтермедії; наступна пара $R-I$ в сукупності ідентифікується з розробковим розділом сонатної структури; третя пара - з репризою, чому сприяє хід тонально-гармонічного процесу (повернення до $d$-moll імперативної теми головної партії та $D$-dur побічної). Четвертий ритурнель tutti 3 подальшим переходом до ліричної теми і скрипкової моторики утворюють коду. 
У другій частині циклу (Langsam, B-dur) Р. Шуман відмовляється від очевидної стилізації, але пристосовує до романтичної інтонаційності типові для музики бароко принципи викладення тематизму та його розвитку. Він звертається до «нескінченного» барокового мелодійного розгортання в партії скрипки, прийому контрапунктичного сполучення двох тем, мелодизації оркестрової фактури, імітаціям в партіях комунікантів.

За традицією класико-романтичного концерту фінал даного циклу (Lebhaft, doch nicht scnell, D-dur) націлений на розкриття співдружності оркестру та соліста і вищої виконавської майстерності останнього. Тут стилізаторські наміри Р. Шумана набувають вигляду карнавального музичного дійства. У калейдоскопі швидкоплинних тем-образів урочистість полонезних ритмоформул змінюється рухом галантного менуету в чергуванні з ліричними фразами, що нагадує діалог персонажівмасок, та посиланнями на теми попередніх частин. Отже, концертність обертається в розумінні Р. Шумана своєю ігровою складовою, очевидні стилізаторські наміри в масштабах циклу - «діалогом стилістик», а через це - «діалогом музично-історичних епох».

Й. Брамс у Першому фортепіанному концерті не займається стилізацією; його метод роботи 3 музичним матеріалом та структурами музично-історичного минулого скоріше можна назвати відсиланням до певних стилістичних прообразів. Йому чужа шуманівська карнавальна гра, переодягнення в «костюми» іншої епохи, створення ефекту перенесення в інший світ, ілюзії присутності в ньому. Подібно до Ф. Медельсона, він мислить музичне мистецтво як єдину духовно-естетичну традицію, універсальну мову, що дозволяє встановити контакт 3 аудиторією, оперуючи явищами, сформованими в композиторській практиці. Тому Й. Брамс обирає для «титульної» теми Першого фортепіанного концерту такий комплекс музично-виразових засобів, який н агадув а в би про образи часів бароко, але не в і д т в о р ю в а в би їх максимально близько до оригіналів. Він використовує щільне звучання струнної групи оркестру, яке привносить в симфонічне tutti «присмак» барокової концертності; рельєфність мелодичної лінії, внаслідок чого у «титульній» темі з'являються риси високої риторики; гучну динаміку, яка надає початковій думці вагомість, притаманну ораторській або проповідницькій промові тобто виставляє знаки типового барокового висловлювання. Отже, при всій «бароковості» початкова тема брамсівського концерту не маркує певну музично-історичну епоху, а запозичує їі прийоми. Звідси - інтегративність мислення Й. Брамса, що дозволяє йому уникнути стилістичних «швів», в той час як Р. Шуман підкреслює їх, грає різними інтонаційними моделями. 
Показово, що Й. Брамс не виводить на поверхню композиційного сценарію логіку побудови концертної форми, хоча й не відмовляється від неї зовсім.

Композитор відроджує у першій частині Першого фортепіанного концерту подвійну експозицію, що, безумовно, дозволяє припустити безпосередній відгук на відновлення цього принципу побудови концертних сонатних allegro в розглянутому творі Р. Шумана. Утім, перше tutti у творі Й. Брамса аж ніяк не асоціюються 3 бароковим ритурнелем. Воно розгорнуте, багатотемне та складене за риторичним принципом $i: m: t$. Друга експозиція також містить низку тем-образів, як переживання оркестрового висловлювання, i не націлена на прояв віртуозної майстерності піаніста. У сукупності ії властивості виявляються вельми далекими від фігураційності, притаманної інтермедійним розділам барокових концертів. Протягом усієї першої частини циклу Й. Брамс використовує принцип чергування tutti та solo, водночас не дотримуючись їх барокового алгоритму. Самостійний вихід оркестру з'являється там i тоді, коли виникає драматургічна необхідність. Обидва комуніканти постійно то взаємодіють у вигляді конфліктного зіткнення, то сумісно беруть участь у розвитку тематичного матеріалу. Отже, їх діалог має беззаперечно симфонічний характер.

У композиції першої частини брамсівського концерту цілковито витримана побудова сонатного allegro. Розділи подвійної експозиції, активної за тематичним і гармонічним розвитком розробки, репризи і коди чітко визначені та не припускають іншого структурно-функціонального тлумачення. Єдине, що надає даній частині циклу присмак іншого жанру, це невеличкий скерцозний епізод у розробці, який свідчить про прояви в сонатній композиції рис поемності.

Треба також відзначити розвиненість оркестрової партії, складність симфонічної фактури, чутливість композитора до тембрових фарб, а також іï активність в кожну мить музичного звучання, що сприяє виникненню складної сольно-оркестрової партитури. В цьому Й. Брамс, безумовно, виступає нащадком Л. ван Бетховена, підхоплюючи лінію його П'ятого фортепіанного концерту. Отже, композитор охоплює майже весь досвід фортепіанного концерту XIX століття і сплавляє різноманітні його прояви в єдине ціле.

Барокові алюзії, що з'явилися в «титульній» темі сонатного allegro Першого фортепіанного концерту Й. Брамса, продовжені в другій його частині (D-dur). Якщо у Р. Шумана повільний розділ циклу наближається до intermezzo і являє собою лірико-поетичне висловлювання, то Adagio Й. Брамса - це справжній «ліричний центр» циклу. В композиції цієї 
частини простежується той принцип зміни tutti та soli, який в сонатному allegro цілковито підкорявся сонатному. Саме тут використовується шуманівський прийом персоніфікації, драматизації партій оркестру i соліста. Глибокий спокій хоральної оркестрової теми змінюється в монолозі фортепіано більш експресивним варіантом. У цілому, соло тут складається з двох варіацій, що чергуються 3 короткими репліками інструментальних груп. Оркестр і надалі, у двох наступних темах, презентованих в монологах соліста, виконує функцію «коментатора». I лише після того, як фортепіанне висловлювання набуває найвищої міри схвильованості, збудженості, пристрасності, оркестр, нарешті, наділяється власною темою та викладає іiі впродовж досить довгого часу в супроводі пасажів солюючого інструмента. В кульмінації, котра розміщена в репризі, обидва партнери беруть участь у створенні драматичної напруги. Наприкінці Adagio Й.Брамс пише невеличку каденцію соліста, що не передбачено законами барокового концерту, але відсилає до класичних зразків цього жанру.

Фінал брамсівського опусу, як і шуманівського, націлює на показ віртуозних можливостей соліста та активність його діалогу з оркестром, тобто на розкриття ігрової сутності концерту i концертності. Він аналогічно шуманівському - написаний в помірному темпі (Allegro non troppo), але в основній, на противагу одноіменній в останній частині концерту Р. Шумана, тональності. Втім, Й. Брамс також завершує концертне змагання в D-dur. Грайливі трелі в партії соліста нагадують про музику «галантної» епохи, а подвійне fugato 3 використанням вихідної теми в розробці рондо-сонати - про барокову традицію. 3 боку концертного діалогу це фугато виступає як його специфічна форма, але реалізована виключно силами оркестру: струнна група презентує тематичний матеріал експозиційного розділу музичної композиції, iï окремі партії та дерев'яні духові інструменти перегукуються в дусі perpetuum mobile барокових загальних форм руху в інтермедійній частині.

Висновки. У науковій літературі під «присвятою» розуміють різноманітні послання конкретним особам, окремі риси яких - особистісні, творчі, біографічні - можуть віддзеркалюватися безпосередньо в музичному просторі композиторського опусу. Про наявність присвяти свідчать авторські словесні повідомлення, вміщені в нотному виданні, які передують власне нотному тексту. Й. Брамс не був схильним до подібних вербально презентованих адрес, але в його творах виявляється значна кількість тематичних «подібностей», що часом наводить на думку про наявність прихованої присвяти. Підгрунтям до подібного тлумачення Першого фортепіанного концерту Й. Брамса слугує барокова забарвленість 
«титульної» теми в $d$-moll, притаманна також Скрипковому концерту Р. Шумана. Досить ймовірно, що думка про власний концертний твір, хоча й приналежний іншій жанровій гілці, була ініційована саме твором Р. Шумана. Втім, увесь подальший рух музичних подій, композиційні засади, розуміння концертного діалогу, тематична робота свідчать скоріше про намір Й. Брамса, відштовхнувшись від вихідної музичної ідеї свого старшого друга, сказати своє слово. Не в останню чергу цьому сприяє обрання не скрипкового, а фортепіанного концерту. Якщо барокові посилання у творі Р. Шумана природно вписалися саме в скрипковий різновид жанру, в якому склалася стала модель концерту для солюючого (концертуючого) інструмента i оркестру, то звернення до фортепіанооркестрового діалогу запрограмувало опору на класико-романтичну традицію. Симптоматично, що поетика показу, характерна для Р. Шумана, обумовлює акцентування концертно-ігрового мислення, а процесуальність поетики становлення, притаманна Й. Брамсу, - «романно-симфонічного», хоча й поза згладжування концертної жанрової семантики. Риси цього мислення у поемному варіанті проступають у розділі побічної партії, де фортепіано доручається монологічне висловлення, що нагадує про ліричні епізоди в композиціях Ф. Ліста.

Очевидно, що подібні вихідні тематичні ідеї обох концертів слугують відправною точкою для зовсім різних, майже протилежних художніх концепцій, що в сукупності з відсутністю авторських свідчень Й. Брамса про «адресність» свого твору не дає можливості погодитися 3 думкою про його присвяту Р. Шуману. Водночас, наявність схожих ініціальних тем розглянутих творів дозволяє вважати брамсівську тему свідомою або позасвідомою ремінісценцією - не тільки музичного образу, народженого фантазією Р. Шумана, але й брамсівської «шуманіани», 3 розгляду якої К. Царьова цілком закономірно починає своє дослідження про німецького майстра [5].

1. Гуляницкая Н. Компаративистика // Гуляницкая Н. Методы науки о музыке. Москва, 2009. C. 69-84.

2. Меркулов А. Из наблюдений над звуковой символикой // Советская музыка. №8. 1985. C. 91-96.

3. Торган Я. Фортепианные концерты Брамса в свете эволюции данного жанра в первой половине XIX века: автореф. дис. ... канд. искусствоведения : 17.00.02. Киев, 1978. 24 с.

4. Фомина Н. Прагматика посвящения в творчестве Сергея Прокофьева : дис. ... канд. искусствоведения : 17.00.03. Харьков, 2014. 198 с.

5. Царева Е. Иоганнес Брамс : монография. Москва : Музыка, 1986. 383 с. 
6. Beyer C. Klavierkonzert in D-moll. op. 15 // Musiker und ihre Werke. Johannes Brahms. Leipzig, 1897. S. 250-265.

7. Geiringer K. Brahms: His Life and Work. Boston and New York, 1936. 432 p.

\section{References}

1. Gulyanitskaya, N. (2009). Comparative studies. In: N. Gulyanitskaya, ed., Methods of the music science. Moscow, pp. 69-84 [in Russian].

2. Merkulov, A. (1985). From observations on sound symbolics. Sovetskaya muzyka, 8, pp. 91-96 [in Russian].

3. Torgan, Y. (1978). Brahms piano concertos in the light of the evolution of this genre in the first half of the XIX century. Extended abstract of $\mathrm{PhD}$ thesis. Kyiv [in Russian].

4. Fomina, N. (2014). Pragmatics of initiation in the works by Sergei Prokofiev. PhD thesis. Kharkiv [in Russian].

5. Tsareva, E. (1986). Johannes Brahms. Moscow [in Russian].

6. Beyer, C. (1897). Klavierkonzert in D-moll. op. 15. In.: Musiker und ihre Werke. Johannes Brahms. Leipzig, pp. 250-265 [in English].

7. Geiringer, K. (1936). Brahms: His Life and Work. Boston and New York [in English].

УДК 78.082 .4

DOI: https://doi.org/10.33643/kmus.2019.58.10

Богдан Решетілов,

аспірант кафедри історії світової музики Національної музичної академії України ім. П. І. Чайковського https://orcid.org/0000-0002-7498-1310 reshebogdan@gmail.com

Bogdan Reshetilov, Postgraduate at the Department of History of World Music, Ukrainian National Tchaikovsky Academy of Music https://orcid.org/0000-0002-7498-1310 reshebogdan@gmail.com

\section{ПАУЛЬ ГІНДЕМІТ. ТЕМА 3 ВАРІАЦІЯМИ «ЧОТИРИ ТЕМПЕРАМЕНТИ» ДЛЯ ФОРТЕПІАНО ТА СТРУННОГО ОРКЕСТРУ: ОСОБЛИВОСТІ ЖАНРУ, КОНЦЕПЦІЯ ЛЮДИНИ}

Статтю присвячено твору Пауля Гіндеміта «Чотири темпераменти», що є жанрово неоднозначним і може трактуватися 3 різних позицій. $€$ аргументи на користь трактовки композиції як балету й концерту. Проте інтонаційно-драматургічний аналіз і розгляд твору в контексті сонатносимфонічного циклу за «концепцією Людини» М. Арановського відкриває нові семантичні вектори. Разом із висвітленням творів інших композиторів, присвячених темі темпераментів людини, особливостей співпраці 3 Л. М'ясіним та ймовірної зацікавленості композитором 